\title{
PENGARUH PENGGUNAAN TEPUNG LIMBAH RUMPUT LAUT (Gracilaria verrucosa) FERMENTASI DALAM RANSUM TERHADAP PROFIL HEMATOLOGIS ITIK PENGGING BETINA
}

\author{
F. Evandharu ${ }^{1}$ Isroli $^{2}$ dan E. Suprijatna ${ }^{2}$ \\ 1) Mahasiswa Fakultas Peternakan Dan Pertanian Universitas Diponegoro \\ Kampus drh. Soejono Koesoemowardojo Tembalang Semarang 50275 \\ E-mail: edjengs@gmail.com \\ ${ }^{2)}$ Fakultas Peternakan dan Pertanian, Universitas Diponegoro \\ Kampus drh. R. Soejono Kusumowardojo Tembalang, Semarang 50275 \\ Diterima: 03 November 2015 \\ Disetujui: 27 Oktober 2016
}

\begin{abstract}
ABSTRAK
Penelitian bertujuan untuk mengetahui pengaruh penggunaan tepung limbah rumput laut fermentasi (TLRLF) terhadap profil hematologis itik Pengging betina. Materi penelitian adalah 125 ekor itik Pengging betina umur 32 minggu. Ransum tersusun dari jagung kuning, bekatul, bungkil kedelai, tepung ikan, minyak nabati, $\mathrm{CaCO}_{3}$, premix, methionin, lysin, tepung sumpil (Brotia costulla), tepung limbah rumput laut (TLRL) dan TLRLF. Rancangan Acak Lengkap (RAL) diterapkan dengan 5 perlakuan, 5 ulangan, T0: ransum kontrol tanpa TLRL; T1: ransum mengandung 15\% TLRL, T2: ransum mengandung 15\% TLRLF; T3: ransum mengandung 17,5\% TLRLF; T4: ransum mengandung 20\% TLRLF. Parameter yang diamati yaitu jumlah eritrosit, kadar hemoglobin, dan kadar hematokrit. Hasil penelitian menunjukkan perlakuan tidak berpengaruh nyata $(\mathrm{P}>0,05)$ terhadap jumlah eritrosit dan kadar hemoglobin, tetapi meningkatkan $(\mathrm{P}<0,05)$ kadar hematokrit.
\end{abstract}

Kata kunci: itik pengging, limbah rumput laut, profil hematologis.

\section{THE EFFECT OF FERMENTED SEAWEED (GRACILARIA VERRUCOSA) BY PRODUCT FLOUR IN THE DIET ON HEMATOLOGY PROFILE OF FEMALE PENGGING DUCK}

\begin{abstract}
This study aims to determine the effect of fermented seaweed by product flour $(F S B P F)$ in rations on hematology profile in female Pengging ducks. The material used is 125 female Pengging duck age of 32 weeks. Rations were used consisting of yellow corn, rice bran, soybean meal, fish meal, premix, $\mathrm{CaCO}_{3}$, methyonin, lysine, coconut oil, Brotia costulla flour, seaweed by product flour (SBPF) and FSBPF. This study used a completely randomized design (CRD) with five treatments and five replications, T0: ration without SBPF ; T1: ration with 15\% SBPF; T2: ration with 15\%FSBPF; T3: ration with 17,5\% FSBPF and T4: ration with 20\% FSBPF. Parameter were, total RBC, hemoglobin and
\end{abstract}


$P C V$. The results showed that the use of FSBPF in rations not significantly effect $(P>0.05)$ the total $R B C$ and hemoglobin, but significantly $(P<0.05)$ increase level on $P C V$.

Keywords: Pengging duck, seaweed by product, hematology profile.

\section{PENDAHULUAN}

Itik Pengging adalah salah satu jenis itik lokal hasil persilangan antara Itik Magelang dengan Itik Mojosari, serta warna bulu pada umumnya didominasi warna bulu Itik Mojosari. Itik Pengging memiliki ciri khusus yaitu warna bulu polos kecoklatan, warna kaki dan paruh hitam, mata lebar, serta ukuran kepala yang kecil dengan leher agak panjang (Setiawan et al., 2013). Penyebarannya di daerah Kab. Boyolali, Kab. Sukoharjo, Kab. Klaten dan Kab. Sragen, Jawa Tengah.

Permasalahan yang mucul dari peternakan itik adalah biaya dan harga pakan yang tinggi. Peternak memerlukan bahan pakan alternatif yang terdapat di daerah sekitar peternakan yang memiliki kandungan nutrisi yang tinggi dan dapat meminimalisir biaya. Bahan pakan alternatif adalah bahan pakan yang belum umum digunakan, mudah didapat, harganya murah dan memiliki kandungan nutrien tinggi, salah satunya yaitu limbah rumput laut. Limbah rumput laut merupakan hasil samping dari budidaya rumput laut berupa sortiran rumput laut setelah panen dan dapat ditemukan di sekitar pantai utara Jawa Tengah.

Limbah rumput laut memiliki kandungan nutrisi seperti polisakarida dan serat; mineral; protein dan asam amino; lemak dan asam lemak; vitamin $\mathrm{B}_{12}, \mathrm{C}$ dan E; polifenol serta karotenoid (Burtin, 2003). Kandungan nutrisi dalam rumput laut yang baik dapat menunjang proses pembentukan darah (hemopoeisis). Zat-zat yang berperan dalam hemopoesis ialah protein, vitamin (asam folat, vitamin B12, vitamin C, dan vitamin $\mathrm{E}$ ), dan mineral (Fe dan $\mathrm{Cu}$ ) (Besuni et al., 2013). Pemberian pakan ternak ayam dengan menggunakan tepung rumput laut (Gracilaria edulis) pada level 2,5 sampai $10 \%$ dari total pakan mampu meningkatkan kesehatan, bobot telur, produksi telur, dan daya tetas (Horhoruw et al., 2009).

Tujuan penelitian adalah mengetahui seberapa besar rumput laut fermentasi dapat dimanfaatkan sebagai bahan pakan untuk meningkatkan profil hematologis itik pengging betina.

\section{MATERI DAN METODE}

Materi penelitian adalah 125 ekor itik Pengging betina umur 32 minggu. Kandang yang digunakan adalah 25 petak kandang litter berukuran $1 \times 1 \times 1 \mathrm{~m}$, masing-masing petak berisi 5 itik. Ransum tersusun dari jagung kuning, bekatul, bungkil kedelai, tepung ikan, minyak nabati, $\mathrm{CaCO}_{3}$, premix, methionin, lysin, tepung sumpil (Brotia costulla), TLRL dan TLRLF. Ransum berdasarkan isoprotein dan isoenergi dengan kandungan PK 18\% serta energi metabolis $2900 \mathrm{kkal} / \mathrm{kg}$.

Limbah rumput laut diperoleh dari desa Randusanga Wetan, Brebes, Jawa Tengah. Pembuatan tepung limbah rumput laut diawali dengan proses seleksi dan pencucian. Menjemur limbah rumput laut hingga kering, kemudian menggilingnya. Proses fermentasi dilakukan dengan mengukus limbah rumput laut 20 menit pada suhu $\pm 100^{\circ} \mathrm{C}$, didinginkan hingga suhu $35^{\circ} \mathrm{C}$. Mencampur Aspergillus niger sebanyak 12 gram per $\mathrm{kg}$ tepung limbah rumput laut. Melakukan pemeraman 2 
minggu secara aerob dengan suhu $35-36^{\circ} \mathrm{C}$ dan kelembaban 70-80\%. Membalik permukaan fermentasi, menjemurnya dengan cahaya matahari selama 1 hari untuk menghentikan proses fermentasi.

Pengambilan data hematologis dilakukan pada umur 40 minggu. Analisis hemoglobin, eritrosit dan hematokrit dilakukan terhadap 25 sampel darah dengan pengambilan 1 sampel secara acak dari setiap unit percobaan. Pengambilan darah dilakukan melalui pembuluh vena brachialis (bagian sayap) menggunakan syringe sebanyak $\pm 5 \mathrm{cc}$, dan segera dimasukkan ke dalam tabung EDTA (Ethylene Diamine Tetraacetic Acid) untuk menghindari pembekuan darah. Semua perhitungan profil darah menggunakan alat Sysmex XS-800i.

Rancangan yang digunakan adalah RAL (Rancangan Acak Lengkap) dengan 5 perlakuan dan 5 ulangan yaitu (T0) ransum kontrol, (TI) ransum dengan penggunaan TLRLNF 15\%, (T2) ransum dengan penggunaan TLRLF 15\%, (T3) ransum dengan penggunaan TLRLF $17,5 \%$ dan (T4) ransum dengan penggunaan TLRLF $20 \%$. Data yang diperoleh dianalisis dengan menggunakan analisis ragam dan uji $\mathrm{F}$ pada taraf $5 \%$, jika terdapat pengaruh perlakuan yang nyata $(\mathrm{P}<0,05)$ maka dilanjutkan dengan uji Duncan.

Tabel 1. Komposisi dan Kandungan Nutrien Ransum Perlakuan

\begin{tabular}{|c|c|c|c|c|c|}
\hline \multirow{2}{*}{ Bahan Pakan } & \multicolumn{5}{|c|}{ Ransum } \\
\hline & T0 & $\mathrm{T} 1$ & $\mathrm{~T} 2$ & T3 & $\mathrm{T} 4$ \\
\hline & \multirow[b]{2}{*}{561} & 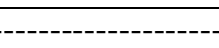 & $---(\%)-$ & ---------- & -- \\
\hline Jagung Kuning & & 49,1 & 48,3 & 46,8 & 45,0 \\
\hline Tepung Rumput Laut & 0 & 15,0 & 0 & 0 & 0 \\
\hline Tepung Rumput Laut Fermentasi & 0 & 0 & 15,0 & 17,5 & 20,0 \\
\hline Bungkil Kedelai & 17,6 & 17,5 & 17,1 & 16,3 & 15,9 \\
\hline Minyak Nabati & 0,7 & 0,7 & 0,5 & 0,4 & 0,4 \\
\hline Bekatul & 13,8 & 6,7 & 8,7 & 8,2 & 8,3 \\
\hline Tepung Ikan & 7,0 & 7,0 & 5,9 & 6,6 & 6,6 \\
\hline $\mathrm{CaCO}_{3}$ & 1,9 & 1,2 & 1,7 & 1,4 & 1,0 \\
\hline Premix & 1,0 & 1,0 & 1,0 & 1,0 & 1,0 \\
\hline Methionin & 0,4 & 0,4 & 0,4 & 0,4 & 0,4 \\
\hline Lysin & 0,5 & 0,4 & 0,4 & 0,4 & 0,4 \\
\hline Tepung Sumpil (Brotia costulla) & 1,0 & 1,0 & 1,0 & 1,0 & 1,0 \\
\hline Jumlah & 100,00 & 100,00 & 100,00 & 100,00 & 100,00 \\
\hline \multicolumn{6}{|l|}{ Kandungan Nutrien : } \\
\hline EM $(\mathrm{kkal} / \mathrm{kg}) *$ & $2.929,29$ & $2.900,66$ & $2.907,52$ & $2.902,74$ & $2.901,84$ \\
\hline Protein kasar(\%) & 18,08 & 18,05 & 18,02 & 18,02 & 18,01 \\
\hline Serat Kasar (\%) & 6,44 & 6,44 & 6,59 & 6,72 & 6,99 \\
\hline Lemak Kasar(\%) & 8,01 & 7,67 & 8,53 & 8,58 & 8,72 \\
\hline $\mathrm{Ca}(\%)$ & 2,48 & 2,44 & 3,96 & 4,01 & 3,91 \\
\hline $\mathrm{P}(\%)$ & 0,72 & 0,60 & 0,60 & 0,61 & 0,61 \\
\hline Methionin (\%) & 0,73 & 0,70 & 0,68 & 0,69 & 0,68 \\
\hline Lysin (\%) & 1,08 & 0,94 & 0,92 & 0,91 & 0,90 \\
\hline Arginin (\%) & 1,25 & 0,43 & 1,09 & 1,08 & 1,06 \\
\hline Harga Pakan (Rp/kg) & $5.589,5$ & $5.207,25$ & $5.182,2$ & $5.115,07$ & $5.065,63$ \\
\hline
\end{tabular}

*Hasil perhitungan berdasarkan rumus Balton menurut Siswohardjono (1982): EM= 40,81 $\{0,87$ (protein kasar+2,25 lemak kasar+BETN)+2,5\} 


\section{HASIL DAN PEMBAHASAN}

Hasil penelitian penggunaan tepung limbah rumput laut fermentasi dalam ransum terhadap efisiensi penggunaan protein itik pengging dapat dilihat pada Tabel 2.

Tabel 2. Pengaruh penggunaan tepung limbah rumput laut fermentasi

\begin{tabular}{|c|c|c|c|c|c|}
\hline \multirow{2}{*}{ Parameter } & \multicolumn{4}{|c|}{ Perlakuan } & \multirow[b]{2}{*}{$\mathrm{T} 4$} \\
\hline & T0 & $\mathrm{T} 1$ & $\mathrm{~T} 2$ & T3 & \\
\hline Jumlah Eritrosit (juta/mm $\mathrm{mm}^{3}$ ) & 2,68 & 2,64 & 2,81 & 2,59 & 2,78 \\
\hline Kadar Hemoglobin (gram/dl) & 13,02 & 12,66 & 13,76 & 12,82 & 13,46 \\
\hline Kadar Hematokrit (\%) & $39,82^{\mathrm{b}}$ & $39,74^{\mathrm{b}}$ & $43,10^{\mathrm{a}}$ & $38,84^{\mathrm{b}}$ & $42,96^{\mathrm{a}}$ \\
\hline
\end{tabular}

\section{Jumlah Eritrosit}

Berdasarkan pada tabel diatas, nilai rataan jumlah eritrosit berada dalam kisaran normal jumlah eritrosit pada itik pengging betina. Hal ini sesuai dengan pendapat Hidayat et al. (2013) bahwa jumlah ratarata sel darah merah pada unggas adalah $1,25-4,50 \mathrm{juta} / \mathrm{mm}^{3}$. Menurut Ismoyowati (2006), rataan profil hematologis itik betina lokal (Itik Tegal) produksi tinggi yaitu 2,30 $\pm 0,27106 / \mu 1$.

Hasil analisis statistik menunjukkan bahwa perlakuan pemberian tepung limbah rumput laut fermentasi sampai tahap pemberian $20 \%$ pada ransum itik pengging betina tidak berpengaruh terhadap jumlah eritrosit $(\mathrm{P}>0,05)$. Hasil ini bisa dipengaruhi oleh umur, jenis kelamin, nutrisi, bangsa, suhu lingkungan dan faktor iklim yang sama. Hal ini sesuai dengan Wardiny et al. (2012) bahwa jumlah eritrosit ini dipengaruhi oleh umur, jenis kelamin, hormon, hipoksia (kekurangan oksigen), aktivitas, nutrisi, produksi telur, bangsa, suhu lingkungan dan faktor iklim. Semua faktor tersebut tidak ada perbedaan sehingga faktor yang memungkinkan mempengaruhi eritrosit adalah tepung rumput laut, namun hasil penelitian ini tepung rumput laut tidak mempengaruhi jumlah eritrosit. Hal ini disebabkan tepung limbah rumput laut tidak mengakibatkan ransum berbeda kadar proteinnya. Nutrisi yang paling berpengaruh terhadap eritrosit adalah protein terutama asam amino yang terdapat di dalam ransum sehingga mampu memperbaiki metabolisme dalam tubuh itik secara optimal. Jumlah eritrosit yang normal juga dapat dijadikan sebagai salah satu indikator bahwa kecukupan protein dan asam amino tetap terjaga (Napirah et al., 2013).

Unsur penting dalam pembetukan eritrosit adalah protein, glukosa, dan unsur makromineral $(\mathrm{Cu}, \mathrm{Fe}, \mathrm{Zn})$. Adanya unsur mikromineral dan vitamin sebagai pelengkap untuk pembentukan eritrosit. Rumput laut kaya akan vitamin dan mineral khususnya vitamin A, B, C, dan D serta mengandung mineral $\mathrm{Fe}$ dan $\mathrm{Ca}$. Menurut Patria et al. (2013) peran vitamin C dalam pembentukan eritrosit terkait dengan fungsi vitamin $\mathrm{C}$ yang mempercepat penyerapan mineral $\mathrm{Fe}$ dari mukosa usus halus dan memindahkannya kedalam aliran darah menuju tulang sumsum yang selanjutnya digunakan untuk membentuk hemoglobin.

\section{Kadar Hemoglobin}

Berdasarkan pada tabel diatas, ratarata kadar hemoglobin pada itik pengging betina yaitu antara 12,66-13,76 gram/dl. Hasil penelitian ini lebih tinggi daripada penelitian Ali et al. (2013) bahwa kadar 
hemoglobin itik lokal yang dihasilkan dari penambahan probiotik dalam ransum yaitu berkisar antara $8,10 \pm 0,79 \mathrm{~g} / 100 \mathrm{ml}$ sampai $11,23 \pm 1,23 \mathrm{~g} / 100 \mathrm{ml}$. Menurut Ismoyowati (2006) bahwa rataan kadar hemoglobin darah itik Tegal berkisar antara 10,95712,171 g/100 ml. Hal tersebut menyebabkan kemampuan membawa oksigen ke dalam jaringan meningkat. Hal ini sesuai dengan Hidayat et al. (2013) bahwa kadar hemoglobin yang rendah menyebabkan kemampuan membawa oksigen ke dalam jaringan menjadi menurun, dan ekskresi $\mathrm{CO}_{2}$ tidak efisien sehingga keadaan dan fungsi sel akan mengalami penurunan.

Hasil analisis statistik menunjukkan bahwa perlakuan pemberian tepung limbah rumput laut fermentasi sampai tahap pemberian $20 \%$ pada ransum itik pengging betina tidak berpengaruh nyata terhadap kadar hemoglobin $(\mathrm{P}>0,05)$. Hal tersebut dipengaruhi oleh konsumsi ransum antar perlakuan yang sama. Konsumsi ransum yang sama mengakibatkan tidak ada perbedaan asupan $\mathrm{O}_{2}$ antar perlakuan sehingga kadar hemoglobin tidak berbeda nyata. Hasil ini dapat dipengaruhi pula oleh umur, spesies, dan pakan yang sama. Jain (1993) dan Wardhana et al. (2001), menyatakan bahwa faktor yang mempengaruhi kadar hemoglobin adalah umur hewan, spesies, lingkungan, musim, pakan, ada tidaknya kerusakan eritrosit, waktu pengambilan sampel, jenis antikoagulan yang dipakai dan metoda yang digunakan. Menurut Ali et al. (2013) bahwa hemoglobin merupakan suatu senyawa kompleks globlin yang dibentuk 4 sub unit, masing-masing mengandung suatu gugusan hem yang dikonjugasi ke suatu polipeptida. Hem adalah turunan porofirin yang mengandung zat besi (Fe). Pembentukan hemoglobin membutuhkan zat besi $(\mathrm{Fe})$ sebagai komponen penyusunnya.

\section{Kadar Hematokrit}

Nilai rata-rata kadar hematokrit pada itik pengging yaitu antara 38,84-42,96\%. Hasil analisis statistik menunjukkan bahwa kadar hematokrit pada perlakuan T2 dan T4 lebih tinggi jika dibandingkan dengan perlakuan T0, T1 dan T3. Penggunaan rumput laut dalam ransum itik pengging betina terbaik pada level penggunaan $15 \%$ dengan difermentasi. Menurut Isroli et al. (2009) bahwa kadar hematokrit yang rendah di dalam tubuh menandakan ternak tersebut sakit, akan tetapi apabila kadar hematokrit di dalam tubuh ternak stabil dan sesuai dengan standar maka ternak dalam kondisi normal atau sehat. Alam dan Qasim (1994) melakukan penelitian pada ternak tikus dengan pemberian ransum yang mengandung tepung rumput laut hingga taraf 20\% membuktikan adanya peningkatan kadar eritrosit dan kadar hematokrit. Penelitian yang telah dilakukan menunjukkan jumlah eritrosit masih berada di kisaran normal sedangkan kadar hematokrit meningkat. Hal ini kemungkinan disebabkan oleh pemberian taraf rumput laut yang berbeda serta besarnya volume sel darah merah (jumlah eritrosit). Meningkatnya kadar hematokrit menunjukkan bahwa pembentukan eritrosit berjalan dengan baik. Hematokrit menunjukkan besarnya volume sel darah merah yang dinyatakan dalam persen (Ali et al., 2013).

Umur itik dapat mempengaruhi nilai hematokrit dikarenakan oleh ukuran dan jumlah eritrosit, perbedaan umur itik dan tingkat produksi dapat mempengaruhi nilai hematokrit. Semakin besar persentase hematokrit maka semakin banyak gesekan yang terjadi di dalam sirkulasi darah pada 
berbagai lapisan darah dan gesekan ini menentukan viskositas, oleh karena itu hematokrit meningkat dengan bersamaan viskositas darah pun meningkat. Kusumasari et al. (2012) menyatakan bahwa kadar hematokrit dipengaruhi oleh faktor eksternal meliputi ransum, konsumsi air, dan suhu lingkungan dan internal meliputi umur, bangsa, jenis kelamin, dan aktivitas ternak. Nilai hematokrit dalam tubuh ternak dapat mengalami penurunan dan peningkatan yang disebabkan oleh kondisi tubuh ternak itu sendiri atau yang biasa disebut homeostatis (Ismail, 2014). Rumput laut menyebabkan kenaikan kadar hematokrit darah itik pengging betina karena tempung rumput laut menaikkan jumlah eritrosit. Data pada Tabel 2. menunjukkan jumlah eritrosit cenderung naik walaupun secara statistik tidak bermakna.

\section{SIMPULAN DAN SARAN Simpulan}

Hasil penelitian dapat disimpulkan bahwa penggunaan tepung limbah rumput laut (G. verrucosa) fermentasi sampai level $20 \%$ dalam ransum dapat menaikkan kadar hematokrit namun tidak mempengaruhi jumlah eritrosit dan kadar hemoglobin pada itik Pengging betina umur 32-40 minggu.

\section{Saran}

Saran penelitian yaitu pemanfaatan tepung limbah rumput laut sebagai pakan itik pengging betina dapat diberikan hingga taraf $15 \%$ karena meningkatkan profil hematologis.

\section{DAFTAR PUSTAKA}

Ali, S. S., Ismoyowati dan D. Indrasanti. 2013. Jumlah eritrosit, kadar hemoglobin dan hematokrit pada berbagai jenis itik lokal terhadap penambahan probiotik dalam ransum. J. Ilmu. Peternakan. 1 (13): 1001-1013

Besuni, A., N. Jafar dan R. Indriasari. 2013. Hubungan asupan zat gizi pembentuk sel darah merah dengan kadar hemoglobin pada ibu hamil di kabupaten Gowa. Program Studi Ilmu Gizi Fakultas Kesehatan Masyarakat Universitas Hasanuddin Makassar.

Burtin, P. 2003. Nutritional value of seaweeds. Electronic Journal of Enviromental, Agric. and Food Chem. 2 (4): 498-503.

Hidayat, W. Isroli dan RR.E. Widiastuti. 2013. Kadar hemoglobin, hematokrit, dan eritrosit burung puyuh jantan umur $0-5$ minggu yang diberi pakan tambahan kotoran walet dalam pakan. Animal Agriculture Journal 2 (1) : 209 216.

Horhoruw, W.M., Wihandoyo dan T. Yuwanta. 2009. Pengaruh pemanfaatan rumput laut Gracilaria edulis dalam pakan terhadap kinerja ayam fase pullet. Buletin Peternakan. 33 (1): 8-16.

Ismail, F. 2014. Profil Hematologis dan Biokimia Darah Ayam Ras Petelur yang Dipelihara Pada Sistem Pemeliharaan Intensif dan FreeRange pada Musim Kemarau. Skripsi. Fakultas Peternakan Universitas Hasanudin, Makasar.

Ismoyowati, T. Yuwanta, J.H.P. Sidadolog dan S. Keman. 2006. Performans Reproduksi Itik Tegal Berdasarkan Profil Hematologis. Fakultas 
Peternakan UNSOED dan Fakultas Peternakan UGM. Animal Production. Vol. 8, No. 2: 88-93.

Jain, N. C. 1993. Essential of Veterinary Hematology. Lea and Febringer, Philadephia.

Kusumasari. Y.F.Y., V.D. Yunianto dan E. Suprijatna. 2012. Pemberian fitobiotik yang berasal dari mahkota dewa (Phaleria macrocarpa) terhadap kadar hemoglobin dan hematokrit pada ayam broiler. Jurnal Aplikasi Teknologi Pangan. 4 (1): 129-132.

Napirah, A., Supadmo dan Zuprizal. 2013. Pengaruh penambahan tepung kunyit (Curcuma domestica Valet) dalam pakan terhadap parameter hematologi darah puyuh (Coturnixcoturnix japonica). Buletin Peternakan. 37 (2): 114-119.

Patria, D.A., K. Praseno dan S. Tana. 2013. Kadar hemoglobin dan jumlah eritrosit puyuh (Coturnix-coturnix japonica Linn.) setelah pemberian larutan kombinasi mikromineral $(\mathrm{Cu}, \mathrm{Fe}, \mathrm{Zn}, \mathrm{Co})$ dan itamin $\left(\mathrm{A}, \mathrm{B}_{1}\right.$, $\left.\mathrm{B}_{12}, \mathrm{C}\right)$ dalam air minum. Buletin Anatomi dan Fisiologi. 21 (1): 2635.

Putranto, I. 2012. Beternak Bebek Peking. Pustaka Baru Press, Yogyakarta.

Setiawan, A. S., L. D. Mahfudz dan Sumarsono. 2013. Efisiensi Penggunaan Protein pada Itik Pengging Jantan yang Diberi Eceng Gondok (Eichhornia Crassipes) Fermentasi dalam Ransum. Agromedia 31 (2) : 9 - 19.

Wardhana, April H, E. Kenanawati, Nurmawati, Rahmaweni dan C.B.
Jatmiko. 2001. Pengaruh Pemberian Sediaan Patikaan Kebo (Euphorbia Hirta L) terhadap Jumlah Eritrosit, Kadar Hemoglobin, dan Nilai Hematokrit pada Ayam yang Diinfeksi dengan Eimeria tenella. Jurnal Ilmu Ternak dan Veteriner. Vol. 6 No. 2 Th. 2001. Bogor.

Wardiny, T.M., Y. Retnani dan Taryati. 2012. Pengaruh ekstrak daun mengkudu terhadap profil darah puyuh starter. J. Ilmu Tek. Pang. 2 (2): 110-120. 